\title{
LIMITING AMINO ACIDS FOR GROWING CATTLE FED DIETS BASED ON SOYBEAN HULLS
}

\author{
H. Greenwood, E. C. Titgemeyer, and C. A. Löest
}

\begin{abstract}
Summary
Ruminally cannulated Holstein steers were used in three nitrogen balance experiments to determine the sequence of limiting amino acids for growing steers fed soybean hull-based diets. The steers in all experiments were fed the same basal diet ( $73 \%$ soybean hulls, $19 \%$ alfalfa, DM basis; formulated to minimize rumen undegradable intake protein and thus maximize microbial protein postruminally) and were given the same intraruminal infusions (400 grams per day acetate; to increase energy supply without increasing microbial protein supply). In experiment 1 , treatments consisted of abomasal infusions of: water (control, no amino acids); Lmethionine; and a mixture of 10 essential amino acids. Nitrogen retention (a measure of protein deposition) was greatest for steers receiving the mixture, and steers receiving methionine alone had greater nitrogen retention than control steers. In experiment 2, treatments consisted of abomasal infusions of the mixture of 10 essential amino acids or the same mixture without lysine. Nitrogen retention tended to be greater for the 10 amino acid mixture than for the mixture without lysine. In experiment 3, threonine, rather than lysine, was removed from the amino acid mixture. Nitrogen retention was not affected by removal of threonine. We conclude that methionine was the first limiting amino acid, threonine was not limiting, lysine appeared to be a limiting amino acid, and one or more untested amino acids in the mixture appeared to be second most limiting. Therefore, our data do not support the generally accepted concept that the sequence of limiting amino acids for steers is methionine, lysine, and threonine when microbial protein is the primary contributor to metabolizable (postruminal) protein.
\end{abstract}

(Key Words: Steers, Requirements, Amino Acids, Nitrogen Balance, Soybean Hulls.)

\section{Introduction}

The use of soybean hulls in growing cattle diets has become popular for economical and nutritional reasons. They are relatively inexpensive and have been shown to provide slightly less energy than corn in certain grower diets. Additionally, the protein fraction of soybean hulls is considered to be highly ruminally degradable, such that they should supply growing cattle with metabolizable (postruminal) protein predominantly of bacterial origin.

Quantifying the limiting amino acid sequence of bacterial crude protein is important, because protein accretion may be limited by postruminal amino acid supply. Knowing the limiting amino acid sequence for steers fed soybean hull-based diets would allow nutritionists to supplement such diets to meet the animals' requirements and maximize protein accretion. Our objective was to determine the limiting amino acid sequence for growing cattle fed soybean hull-based diets.

\section{Experimental Procedures}

Experiment 1 used five steers $(440 \mathrm{lb})$ in a replicated $3 \times 3$ Latin square with one missing steer. Periods were 7 days with 3 days for adaptation and 4 days for collection of feces and urine. Steers were housed in individual metabolism crates and received $7.5 \mathrm{lb} /$ day (as fed) of the basal diet (Table 1) 
in two equal portions. The diet was formulated to minimize ruminally undegradable intake protein supply, thus maximizing microbial protein postruminally. Intraruminal infusion of 400 grams/day of acetate was provided to each steer to increase the energy supply without increasing microbial protein supply. Treatments consisted of abomasal infusions of (grams/day): a) water (control, no amino acids); b) L-methionine (10); and c) a mixture of 10 amino acids that included L-methionine (10), L-lysine (15.8), L- histidine (7.4), L-phenylalanine (10), Ltryptophan (4.9), L-leucine (20), L-isoleucine (10), L-valine (10), L-arginine (10), and Lthreonine (10).

Table 1. Composition of the Basal Diet

\begin{tabular}{lc}
\hline Ingredient & \% of DM \\
\hline Soyhulls & 72.6 \\
Alfalfa & 19.4 \\
Molasses & 4.8 \\
Dicalcium phosphate & \\
$\quad(16.5 \%$ Ca, 21\% P) & 1.6 \\
Sodium bicarbonate & .8 \\
Magnesium oxide & .3 \\
Trace mineralized salt & .17 \\
Vitamin mixture & .17 \\
Elemental sulfur & .16 \\
\hline
\end{tabular}

Experiment 2 used five steers in a 2-period crossover design. Diets, intraruminal infusions, and experimental conditions were similar to those in experiment 1 . Treatments included the same amino acid mixture and the mixture with lysine deleted (9 amino acids).

Experiment 3 used six steers (427 lbs) in a 2-period crossover design with procedures similar to those experiments 1 and 2 except steers were fed $7.7 \mathrm{lb} /$ day (as fed) of the basal diet. Treatments included the 10 amino acid mixture, with lysine increased from 15.8 to 19.7 grams/day, or the mixture with threonine deleted (9 amino acids).

\section{Results and Discussion}

Experiment 1. Nitrogen retention (Table 2 ) was greatest $(\mathrm{P}<.05)$ for steers that received all 10 of the amino acids (13.7 grams/day). Steers that received only methionine had greater $(\mathrm{P}<.05)$ nitrogen retention (7.9 grams/day) than control steers (5.4 grams/day). The increase in nitrogen retention when methionine alone was provided illustrates that methionine was the first limiting amino acid. The additional increase in nitrogen retention when all 10 amino acids were provided indicates that one or more of the other amino acids in the mixture besides methionine also was limiting.

Table 2. Nitrogen Balance of Steers Supplemented with Amino Acids (Exp. 1)

\begin{tabular}{lcccc}
\hline \multirow{2}{*}{ Nitrogen } & No & & 10 \\
& AA $^{1}$ & Methionine & AA $^{1}$ & SEM \\
\hline ------- (grams/day) & ------- \\
Intake & $57.3^{\mathrm{c}}$ & $58.2^{\mathrm{b}}$ & $73.6^{\mathrm{a}}$ & .02 \\
Fecal & 26.5 & 25.9 & 27.8 & .75 \\
Urinary & $25.4^{\mathrm{b}}$ & $24.4^{\mathrm{c}}$ & $32.1^{\mathrm{a}}$ & .27 \\
Retention & $5.4^{\mathrm{c}}$ & $7.9^{\mathrm{b}}$ & $13.7^{\mathrm{a}}$ & .66 \\
\hline${ }^{1} \mathrm{AA}=$ amino acids. \\
a, b, cMeans within rows without common super- \\
script differ (P<.05).
\end{tabular}

Experiment 2. Steers receiving all 10 amino acids (Table 3$)$ tended $(\mathrm{P}<.09)$ to have greater nitrogen retention (19.0 grams/day) than those receiving the mixture without lysine (16.3 grams/day). This illustrates that the basal lysine supply limited protein deposition. However, the decrease in nitrogen retention when lysine was removed from the mixture ( 2.7 grams/day) was less then that observed when the remaining nine amino acids were removed in experiment 1 (5.8 grams/day), indicating that lysine was not the second most limiting amino acid, but rather that one or more of the other amino acids in the mixture was more limiting than lysine. 
Experiment 3. Nitrogen retention (Table 4) was not different between steers receiving all 10 amino acids (17.8 grams per day) or those receiving the mixture without threonine (17.3 grams per day), illustrating that protein deposition was not limited by threonine supply.

Table 3. Nitrogen Balance of Steers Supplemented with Amino Acids (Exp. 2)

\begin{tabular}{|c|c|c|c|}
\hline Nitrogen & $\begin{array}{l}\text { Without } \\
\text { Lysine }\end{array}$ & $\begin{array}{c}\text { With } \\
\text { Lysine }\end{array}$ & SEM \\
\hline \multicolumn{4}{|c|}{--- (grams/day) ---- } \\
\hline Intake & $73.2^{b}$ & $76.0^{\mathrm{a}}$ & .13 \\
\hline Fecal & 28.5 & 29.3 & .33 \\
\hline Urinary & 28.4 & 27.7 & .43 \\
\hline Retention & $16.3^{\mathrm{d}}$ & $19.0^{c}$ & .74 \\
\hline
\end{tabular}

$\overline{\mathrm{a}, \mathrm{b}}$ Means within rows without common superscript differ $(\mathrm{P}<.05)$.

${ }^{\mathrm{c}, \mathrm{d}}$ Means within rows without common superscript differ $(\mathrm{P}<.09)$.
We conclude that methionine was the first limiting amino acid and that threonine was not limiting for steers fed soybean hull-based diets. Lysine appeared to be a limiting amino acid, but one or more of the untested amino acids in the mixture appeared to be second most limiting. Our data do not support the generally accepted concept that the sequence of limiting amino acids for steers is methionine, lysine, and threonine when microbial protein is the primary source of metabolizable protein.

Table 4. Nitrogen Balance of Steers Supplemented with Amino Acids (Exp. 3)

\begin{tabular}{lccc}
\hline Nitrogen & $\begin{array}{c}\text { Without } \\
\text { Threonine }\end{array}$ & $\begin{array}{c}\text { With } \\
\text { Threonine }\end{array}$ & SEM \\
\hline \multirow{4}{*}{ Intake } & 78.2 & 79.4 & \\
Fecal & 31.8 & 32.7 & .53 \\
Urinary & 29.0 & 28.8 & .55 \\
Retention & 17.3 & 17.8 & .26 \\
\hline
\end{tabular}

